\title{
PALAEOGEOGRAPHIC AND PALAEOCEANOGRAPHIC IMPLICATIONS OF NEW AND REVISED BIO-CHRONOSTRATIGRAPHIC CONSTRAINTS FROM THE PROFITIS ILIAS UNIT (RHODES, GREECE)

\author{
T. DANELIAN ${ }^{1}$, M. BONNEAU ${ }^{2}$, J.P. CADET ${ }^{2}$, A. POISSON ${ }^{3} \&$ B. VRIELYNCK $^{1}$
}

\section{ABSTRACT}

Middle Oxfordian-early Kimmeridgian radiolaria, extracted from the top of radiolarites of Profitis Ilias unit (Rhodes island), suggest that the latter are essentially Middle Jurassic in age and the overlying siliceous shales Late Jurassic. The previously identified Calpionellid horizon at the top of Profitis Ilias siliceous marls is now regarded as early Valanginian in age. The above chronostratigraphic constraints allow tentative correlations to be made between Profitis Ilias and Pindos-Olonos sedimentary units. Finally, the palaeoceanographic significance of the studied series in Rhodes and potentially similar pelagic sequences in the Marmaris area of Turkey are discussed.

KEYWORDS : Radiolaria, Radiolarites, Rhodes, Greece, Hellenides, Taurides

\section{INTRODUCTION}

One of the major problems that still remains unsolved in Eastern Mediterranean geology is the connection of Mesozoic sedimentary sequences between the Hellenides, in Greece, and the Taurides, in southern Turkey (Bernoulli et al. 1974, Aubouin et al. 1976, Harbury \& Hall 1988). This is true despite the fact that these areas are amongst the best studied parts of the Alpine mountain belts which derived after the closure of Tethys.

Improved understanding of the Mesozoic-early Tertiary geological evolution of individual areas in the SE Aegean is of key importance for meaningful correlation of tectonic and palaeogeographic units between Greece and Turkey. For this reason we recently undertook new fieldwork on the island of Rhodes (Fig. 1A) to improve our understanding of the stratigraphy of the Profitis Ilias unit -an essentially pelagic carbonate sequence- and its tectonic relation to adjacent units (i.e. platform/slope sequences, ophiolites).

The particular interest of this unit is that for a long time it has been considered as the easternmost lateral extension of the Pindos-Olonos zone, based essentially on studies which were conducted over 25 years ago (Orombelli \& Pozzi 1967, Aubouin \& Dercourt 1970, Aubouin et al. 1976). More recent studies disputed this conclusion, arguing that the Profitis Ilias sedimentary sequence originated from a basin situated at a further external palaeogeographic position than the Gavrovo-Tripolitsa zone (Harbury \& Hall 1988). However, no comprehensive stratigraphic work has been undertaken since 1975 on the Profitis Ilias sedimentary sequence, despite major progress in our understanding of the Pindos-Olonos zone stratigraphy in mainland Greece and the Peloponnese (Fleury 1980, Thisbault et al. 1981, De Wever \& Cordey 1986) and/or in the light of modern radiolarian taxonomy and biostratigraphy.

In this paper we revise the Jurassic to Lower Cretaceous stratigraphy of the Profitis Ilias sedimentary sequence in the light of some preliminary bio-chronostratigraphic results based on extracted radiolaria. We further compare the Profitis Ilias lithostratigraphic units with formally defined formations of the Pindos-Olonos zone in mainland Greece. Finally, we dicuss the palaeoceanographic significance of Middle/Late Jurassic radiolarites and Lower Cretaceous carbonates of the Profitis Ilias sequence.

\section{GEOLOGICAL AND STRATIGRAPHIC FRAMEWORK}

The Profitis Ilias unit crops out in the northern-central part of the island of Rhodes (Fig. 1B); it is essentially composed of pelagic carbonate and siliceous sedimentary rocks covering the Late Triassic to Late Cretaceous interval ; it is thrusted over the Archangelos unit -a Mesozoic platform/slope sedimentary sequence- and is

1. Département Géologie Sédimentaire, UPMC, CRNS-ESA 7073, C.104, 4, place Jussieu, 75005 Paris

2. Département de Géotectonique, UPMC, CNRS-ESA 7071, C.129, 4, place Jussieu, 75005 Paris

3. Université PARIS XI, Centre d'Orsay, 91405 Orsay Cedex 
tectonically overlain by ophiolitic rocks (Renz 1929, Orombeli \& Pozzi 1967, Mutti et al. 1970, Leboulenger \& Matesco 1975, Aubouin et al. 1976).

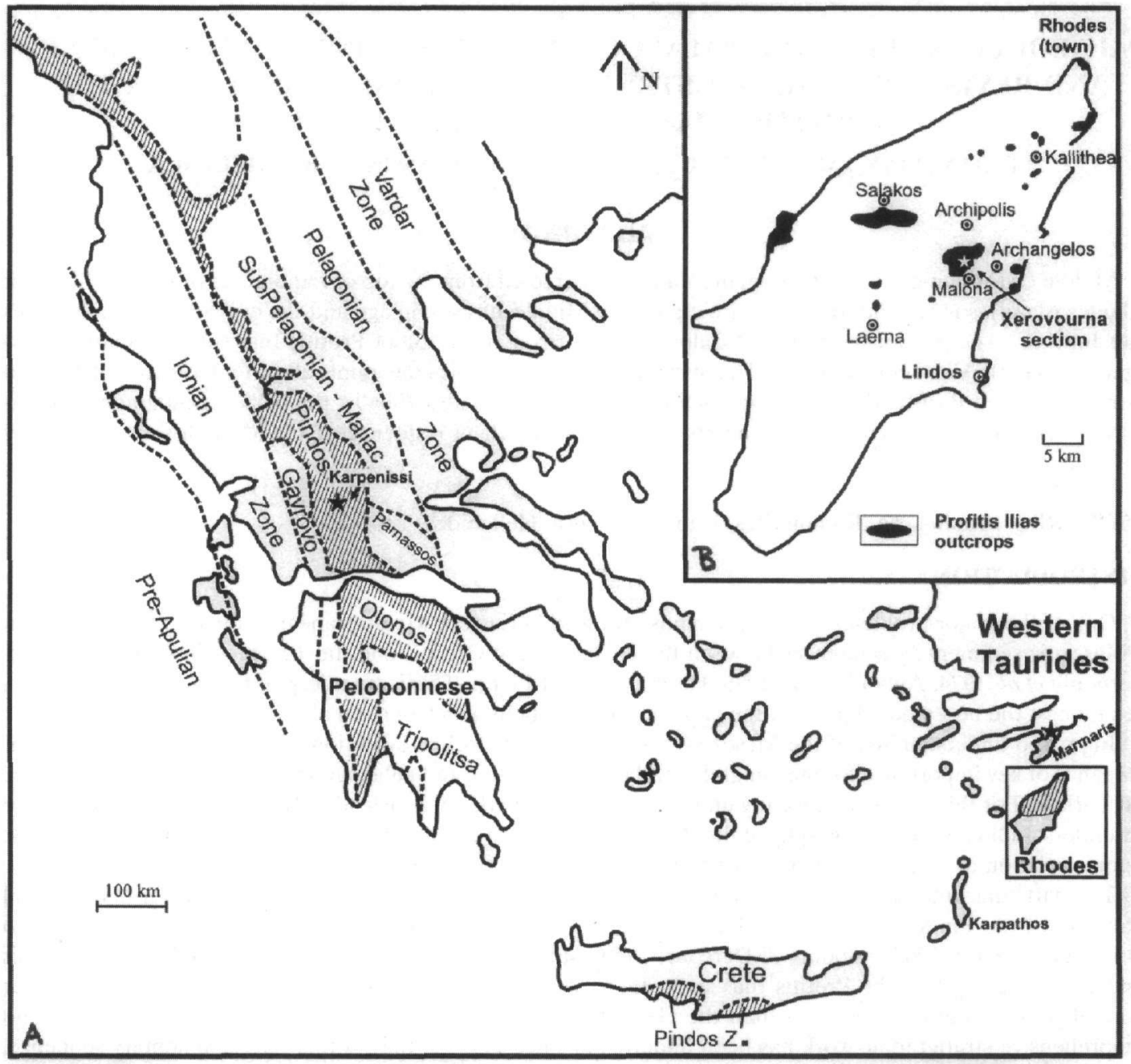

Figure 1. A) Outline of the main Mesozoic palaeogeographic zones in Greece. B) Ouline map of Rhodes including the main outcrops of the Profitis Ilias unit (after Leboulenger \& Matesco 1975).

The oldest known sedimentary rocks assigned to the Profitis Ilias unit are Carnian alternations of sandstones and marls, containing some limestone intercalations. They are overlain by siliceous limestones with Halobia, dated as Norian in age. Thinly-bedded Liassic(?) limestones with chert nodules follow upwards, which are overlain by brown-rose marly and breccia limestones. Several tens of meters of undated red-brownish radiolarites (cyclic alternations of radiolarian chert beds and shaly intervals) punctuate the essentially carbonate sequence with an easily recognizable lithology. Siliceous marly shales overly the radiolarites, passing upwards to siliceous marls, at the top of which a Calpionellid horizon was reported (Leboulenger \& Matesco 1975). Considered at the time as Berriasian, the age of this level is now doubtful and likely to be late Valanginian, as we discuss further below.

Pelagic limestones with minor intercalations of marly and siliceous intervals follow further up the sequence and they are well dated by means of planktic foraminifera. It is noteworthy that ophiolite-derived fragments are reported in one Campanian intercalation of breccia limestone (Leboulenger \& Matesco 1975). Finally, the Maastrichtian flysch ends the sedimentary cycle. 


\section{PREVIOUS RADIOLARIAN DATA}

A single radiolarian species (Lithocampe mediodilatata) was identified by Riedel (in Leboulenger \& Matesco, 1975 ) in the last marly limestone beds underlying the radiolarites of the Profitis Ilias unit. A Late Jurassic (Tithonian) age was suggested at the time for the radiolarites and accepted as such in later works (Harbury \& Hall 1988). However, this early attempt to date the Profitis Ilias radiolarites is over 20 years obsolete, as modern taxonomy and the first biozonations for Mesozoic radiolaria were only established in the late seventies (i.e. Pessagno 1977). The radiolarian morphotypes assigned to L.mediodilatata are now known under the binomial Mirifusus dianae (Róst) s.l., a species comprising 3 subspecies and covering the Mid Jurassic (late Bathonian/ early Callovian) to Early Cretaceous (late Hauterivian) interval (see Baumgartner et al. 1985a).

\section{Pindos-Olonos Profitis Ilias}

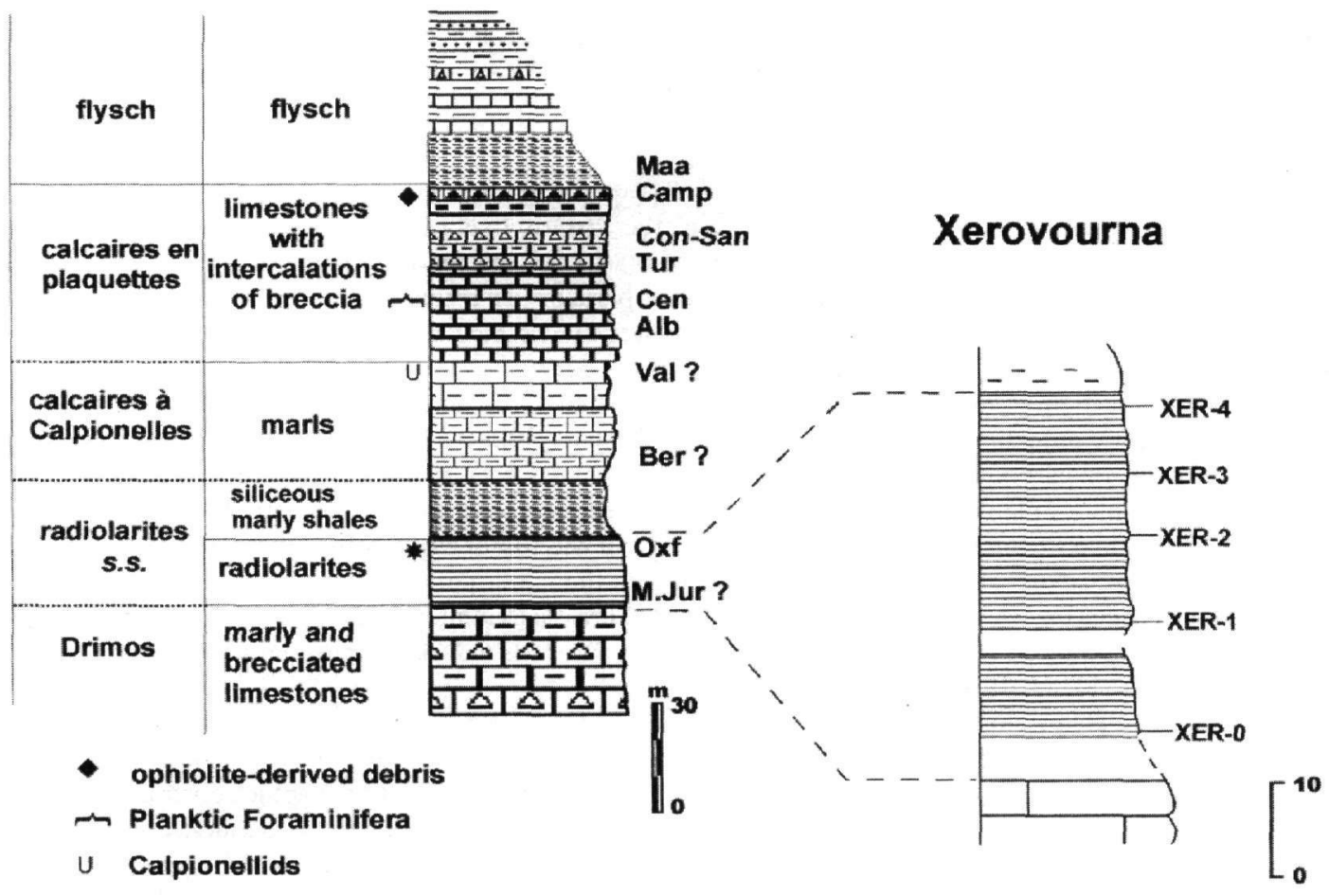

* Radiolaria

Figure 2. Jurassic and Cretaceous synthetic log of the Profitis Ilias unit, based on observations along several sections by Leboulenger \& Matesco (1975, modified). On the right is presented the detailed lithostratigraphy of radiolarites at the Xerovourna section, with the position of samples studied herein. On the left, a tentative correlation is made with the lithostratigraphic units of Pindos-Olonos Zone, as defined by Fleury (1980).

\section{NEW RESULTS}

In order to improve the chronostratigraphic framework of the Profitis Ilias radiolarites and overlying sediments, we visited the Xerovourna section, situated west of the village of Archangelos, at the eastern part of the island (Fig. 1B). The section is more precisely situated $3 \mathrm{~km}$ north of the village of Malona and it was already carefully described (Leboulenger \& Matesco 1975).

Radiolarites and overlying sedimentary rocks were sampled on the southwestern flank of the valley, starting from the bottom of the stream upwards. The contact with the underlying limestones was not observed, as it is covered by scree. Radiolarites here are about 40 metres thick, although their original thickness might be slightly exagerated due to folds, present in some parts of the section (i.e. between samples XER-1 and XER-2 on Fig. 2). Five samples were collected throughout the radiolarian chert sequence, but only one sample (XER-4), coming 
from the top of the formation, yielded a well-preserved radiolarian assemblage which allows for a confident age assignement.

The following radiolaria were identified:

Acanthocircus suboblongus minor Baumgartner in Baumgartner et al. 1995b(Fig. 3a)

Archaeodictyomitra labronica Chiari, Cortese \& Marcucci in Chiari et al., 1997 (Fig. 3b)

Cinguloturris (?) venusta Chiari, Cortese \& Marcucci in Chiari et al., 1997 (Fig. 3c)

Sethocapsa leiostraca Foreman 1973

Parvicingula dhimenaensis Baumgartner 1984 s.l.

Transhsuum maxwelli (Pessagno 1977) gr. (Fig. 3d)

Williriedellum crystallinum Dumitrica 1970 (Fig. 3e)

Zhamoidellum ovum Dumitrica 1970 (Fig. 3f)

The identified radiolarian species characterize the Unitary Association Zones (UAZ) 9-10 of the recently established biozonation by Baumgartner et al. (1995a); they can be therefore correlated with the middle-late Oxfordian to early Kimmeridgian time interval. Moreover, A.labronica and C.(?)venusta are only known from the UAZ 8-9 so far (Chiari et al. 1997), which might indicate that the age of sample XER-4 is limited to the UAZ 9 (middle-late Oxfordian).

\section{DISCUSSION}

Assuming that the average sedimentation rate of the Profitis Ilias radiolarites (average rate for lithified sediments) is comparable to the one estimated for radiolarites of the Pindos-Olonos Zone (1.8-2 m/Ma ; De Wever \& Cordey 1986), it is likely that the median-lower parts of this formation in Rhodes are Middle Jurassic in age. It is now well-established that the Middle Jurassic was a favorable time for the accumulation of radiolarites in western Tethyan basins (De Wever et al. 1993). This is partly due to the estuarine circulation of western Tethys, drawing nutrients from the Palaeopacific (Baumgartner 1987) and favoring the bloom of radiolaria. In addition, the drastic reduction, since the Bajocian, of carbonate production on the platforms, cut off any major input of periplatform carbonate ooze into the basins (Bartolini \& Cecca 1999), which were starved already from any substantial input of planktic calcareous productivity (i.e. calcareous nannofossils) in pre-Cretaceous times.

Given the middle Oxfordian-early Kimmeridgian age of the top of Profitis Ilias radiolarites, the overlying siliceous and slightly marly shales, could be correlated with the upper part of Radiolarites s.s. formation of the Pindos-Olonos zone (Fig. 2). The latter is essentially Late Jurassic (Kimmeridgian-Tithonian) in age (De Wever \& Cordey 1986) and often contains centimeter-thick shaly intervals and thin limestone beds intercalated with radiolarian cherts (Fleury 1980).

The Calpionellid limestones («Calcaires à Calpionelles»; late Tithonian to early Valanginian ; Fleury 1980) overlying the Radiolarites s.s. of the Pindos-Olonos Zone are of particular significance. This is because the presence of Calpionellids in these limestones provides both precious chronostratigraphic constraints and identification of a marker lithostratigraphic unit within the Pindos-Olonos sedimentary sequence (Fleury 1980, Thitbault et al. 1981). In this context, the Calpionellid level reported by Leboulenger \& Matesco (1975) at the top of the siliceous marls at Xerovourna section is of particular importance. It is one amongst the rare Profitis Ilias outcrops on Rhodes island which clearly display the passage of (Middle-)Late Jurassic radiolarites to Early Cretaceous micritic limestones. The age of this Calpionellid horizon has been considered as late Berriasian, based on the identification of the following assemblage : Calpionellopsis oblonga (CAD.), C.simplex (COL.), Calpionellites darderi (COL.), Calpionella elliptica CAD., Tintinopsella carpathica (MURG. \& FIL.) and T.longa (COL.). However, the previoulsy assigned Berriasian age is questionable, because $C$. darderi is a species restricted in the early Valanginian and it does not co-occur with C. elliptica (see Remane, 1985). It is likely that the latter species is misidentified, in which case the age of this Calpionellid horizon at Xerovourna would be rather the early Valanginian. For this reason, the base of the marly unit at Xerovourna (which reflects a substantial increase of the sedimentary sequence in carbonate content following the underlying siliceous shales) is tentatively correlated with the base of the Calpionellid limestone formation of the Pindos-Olonos zone. However, further biostratigraphic work is needed to validate this hypothesis.

As discussed by Mpodozis (1977) and Fleury (1980), the bulk of the Pindos-Olonos' Calpionellid limestones is made of calcareous nannofossils (Maiolica facies). Their accumulation in the Pindos-Olonos basin is recorded since the Late Tithonian, at the same time as in a great number of western Tethyan and Atlantic basins, reflecting a major facies change (radiolarite to Maiolica limestone) in all these basins, regardless of their palaeogeographic setting (Bernoulli 1972; Fourcade et al. 1993).

It is likely that the "Maiolica event" resulted from the response of calcareous nannoplankton to environ- 


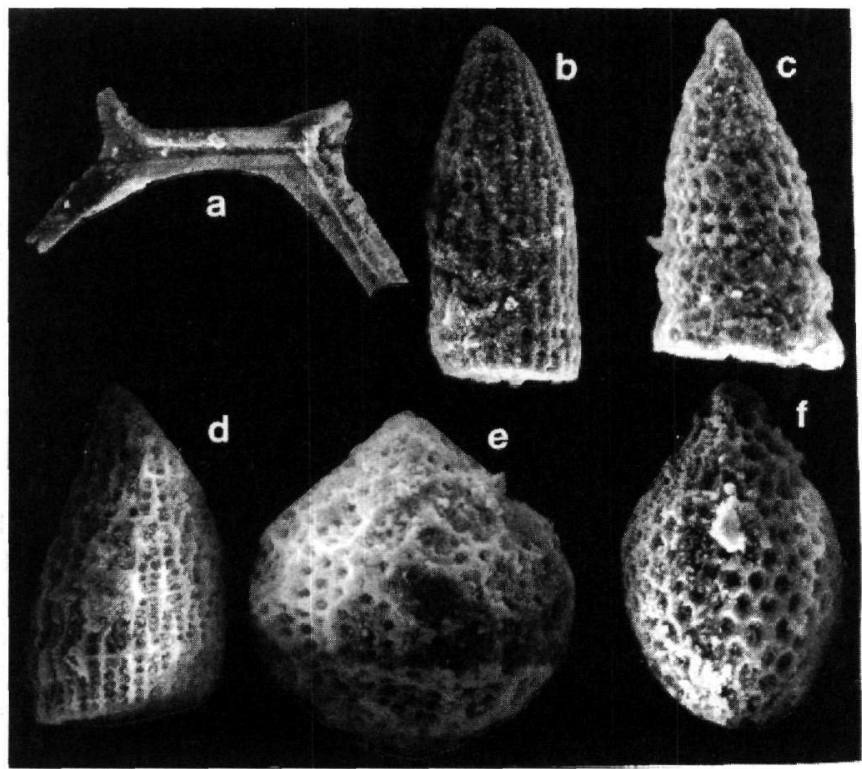

Figure 3. Scanning electron micrographs of some age diagnostic radiolarian species from the top of Xerovourna radiolarites. All illustrated species were extracted from sample XER-4 a) Acanthocircus suboblongus minor, $x 150$; b) Archaeodictyomitra labronica, x200; c) Cinguloturris (?) venusta, x300; d) Transhsuum maxwelli, $x 150$ (proximal part is broken); $e$ ) Williriedellum crystallinum, $x 300 ; f$ ) Zhamoidellum ovum, $x 320$.

mental/oceanographic changes (i.e. migration of calcareous nannofossils from the shallow shelves and epicontinental seas to the open ocean; Roth, 1986, 1989), in relation to the combined effect of climatic and tectonic causes.

\section{CONCLUSIONS}

Preliminary palaeontological and biostratigraphic results on extracted radiolaria from the top of Profitis Ilias radiolarites allow for a middle Oxfordian to early Kimmeridgian (probably only Oxfordian) age assignement. The previously assigned Berriasian age to the Calpionellid assemblage identified at the top of the siliceous marls at Xerovourna is questionable and more likely to be early Valanginian.

Based on the above new and revised chronostratigraphic constraints the following comparison is suggested with respect to Pindos-Olonos formations :

The Profitis Ilias radiolarites can be correlated with the lower and middle parts of Radiolarites s.s. formation, while the upper part of the latter could be represented in Rhodes by the siliceous shales overlying the Profitis Ilias radiolarites. We tentatively correlate the Profitis Ilias siliceous marls with the Calpionellid limestones of Pindos-Olonos.

Consequently, our results enhance the correspondance between the Profitis Ilias and Pindos-Olonos sedimentary sequences, pointed out in previous works (Leboulenger \& Matesco 1975, Aubouin et al. 1976). They highlight the similarities of the Middle Jurassic to Lower Cretaceous sedimentological evolution of sequences which are today approximately $900 \mathrm{~km}$ apart along the hellenic arc (i.e. between Karpenissi and Xerovourna). Mesozoic pelagic sedimentary sequences recording a similar evolution as the Pindos-Profitis Ilias series are also present in the Marmaris area of SW Turkey (the Turun $\eta$ Subgroup; Ersoy 1995) and are likely continued eastwards in the western Tauride mountain belt (Senel 1997, Marmaris and Fethiye maps).

\section{ACKNOWLEDGMENTS}

Financial support from the CNRS (FR32 and ESA 7073) is greatly acknowledged). J.Saintfourges and R.Pussin assisted with laboratory work, E.Masure with the SEM, Ph.Ranguis with photography and C.Abrial with draw- 


\section{REFERENCES}

AUBOUIN J. \& DERCOURT J. (1970). Sur la géologie de l'Egée : regard sur le Dodécanèse méridional (Kasos, Karpathos, Rhodes), Bull. Soc. Géol. France, (7), 12: 455-472.

AUBOUIN J., BONNEAU M., DAVIDSON J., LEBOULENGER P., MATESCO S. \& ZAMBETAKIS A. (1976). Esquisse structurale de l'Arc égéen externe : des Dinarides aux Taurides. Bull. Soc. Géol. France , (7), XVII, $n^{\circ} 2: 327-336$.

BARTOLINI, A. \& CECCA, F., 1999. 20 My hiatus in the Jurassic of Umbria-Marche Apennines (Italy) : carbonate crisis due to eutophication. C.R.A.S. Paris, 329: 587-595.

BAUMGARTNER P.O. (1984) . Middle Jurassic-Early Cretaceous low-latitude radiolarian zonation based on Unitary Associations and age of Tethyan radiolarites. - Eclogae Geol. Helv., 77/3 : 729-837.

BAUMGARTNER, P.O., 1987. Age and genesis of Jurassic Radiolarites. Eclogae geol. Helv., 96/3: 601-626.

BAUMGARTNER, P.O., BARTOLINI, A., CARTER, E.S., CONTI, M., CORTESE, G., DANELIAN, T., DE WEVER, P., DUMITRICA, P., DUMITRICA-JUD, R., GORICAN, S., GUEX, J., HULL, D.M., KITO, N., MARCUCCI, M., MATSUOKA, A., MURCHEY, B., O'DOGHERTY, L., SAVARY, J., VISHNEVSKAYA, V., WIDZ, D. \& YAO, A. (1995a). Middle Jurassic to Early Cretaceous Radiolarian Biochronology of Tethys based on Unitary Associations. In Middle Jurassic to Lower Cretaceous Radiolaria of Tethys: Occurrences, Systematics, Biochronology, (eds P.O. Baumgartner et al.), pp. 1013-1048. Mémoire de Géologie (Lausanne) 23.

BAUMGARTNER, P.O., O'DOGHERTY, GORICAN, S., DUMITRICA-JUD, R., DUMITRICA, P., PILLEVUIT, A., URQUHART, E., MATSUOKA, A., DANELIAN, T., BARTOLINI, A., CARTER, E.S., DE WEVER, P., KITO, N., MARCUCCI, M., \& STEIGER, T., (1995b). Radiolarian catalogue and systematics of Middle Jurassic to Early Cretaceous Tethyan genera and species. In Middle Jurassic to Lower Cretaceous Radiolaria of Tethys: Occurrences, Systematics, Biochronology, (eds P.O. Baumgartner et al.), pp. 37-685. Mémoire de Géologie (Lausanne) 23.

BERNOULLI, D., 1972. North Atlantic and Mediterranean mesozoic facies: a comparaison. In: C.D. Holister, J.I. Ewing et al., Init. Rep. Deep Sea Drill. Proj., XI: 801-881.

BERNOULLI D., DE GRANCIANSKY P.C. \& MONOD O. (1974). The extension of the Lycian nappes (SW Turkey) into the Southeastern Aegean islands. Eclogae Geol. Helv., 67: 4-90.

CHIARI, M., CORTESE, G., MARCUCCI, M. \& NOZZOLI, N. (1997). Radiolarian biostratigraphy in the sedimentary cover of the ophiolites of south-western Tuscany, Central Italy. Eclogae geologicae Helvetiae, 90 : 55-77.

DE WEVER P. \& CORDEY F. (1986). Datation par les radiolaires de la formation des radiolarites s.s. de la série du Pinde-Olonos (Grèce) : Bajocian( ?) - Tithonique. Mar. Micropal., 11 : 113-127.

DE WEVER, P., AZÉMA, J. \& FOURCADE, E., 1994. Radiolaires et Radiolarites: production primaire, diagenèse et paléogéographie. Bull. Centres Rech. Explor.-Prod. Elf Aquitaine, 18(1): 315-379.

DUMITRICA, P. (1970). Cryptocephalic and cryptothoracic Nassellaria in some Mesozoic deposits of Romania. Revue roumaine de Géologie, Géophysique et Géographie, Série de Géologie 14, 45-124.

ERSOY S. (1995). The syn-collisional deep-water sediments of the Marmaris Complex as a part of the Lycian Nappes, the SW Türkiye. Int. Earth Sc. Coll. Aegean Reg., 9-14 Oct.'95, Izmir-Güllük, Turkey, Proc. Vol. 1 : 95-111

FLEURY J.-J. (1980) Les zones de Gavrovo-Tripolitza et du Pinde-Olonos (Grèce continentale et Péloponnèse du Nord). Evolution d'une plate-forme et d'un bassin dans leur cadre alpin. Soc. Géol. Nord Publ., Lille, 4, 651 p.

FOREMAN H. (1973). Radiolaria from DSDP Leg 20. In B.C. Heezen, J.D. MacGregor et al. Eds. D.S.D.P. Init.Reports, U.S. Government Printing Office, Washington, D.C., 32 : 579-676.

FOURCADE, E., AZÉMA, J., CECCA, F., DERCOURT, J., GUIRAUD, R., SANDULESCU, M., RICOU, L.E., VRIELYNCK, B., PETZOLD, M. AND COTTEREAU, N., 1993. Late Tithonian (138 to 135 Ma). In: J. Dercourt, L.E. Ricou and B. Vrielynck (Editors), Atlas Tethys Paleoenvironmental Maps. Explanatory Notes. Gauthier-Villars, Paris: 113-134.

HARBURY N.A. \& HALL R. (1988). Mesozoic extensional history of the southern Tethyan continental margin in the SE Aegean. J. Geol. Soc., London, 145: 283-301.

LEBOULENGER P. \& MATESCO S. (1975). Contribution à l'étude géologique de l'arc égéen. L'île de Rhodes. Unpublished Ph.D. thesis, Univ. Paris VI, 217p.

MPODOZOIS C. (1977). Etude géologique de la région d'Agrapha (zone du Pinde, Evritanie, Grèce). Thèse $3^{\mathrm{e}}$ 
cycle, Univ. Paris.

MUTTI E., OROMBELLI G. \& POZZI R. (1970). Geological studies on the Dodecanese Islands (Aegean Sea). Geological Map of the Island of Rhodes (Greece) explanatory notes. Ann. Géol. Pays Hell., 22: 77-226.

OROMBELLI G. \& POZZI R. (1967). Il Mesozoico nell'Isola di Rodia (Grecia). Riv. Ital. Paleont., 73(2) : 409536.

PESSAGNO, E.A.Jr. 1977. Upper Jurassic Radiolaria and radiolarian biostratigraphy of the California Coast Ranges. Micropaleontology 23(1), 56-113.

REMANE, J., 1985. Calpionellids. In: H.M. Bolli, J.B. Saunders and K. Perch-Nielsen (Editors), Plankton Stratigraphy. Cambridge Univ. Press: 555-572.

RENZ C. (1929). Geologische Untersuchungen auf den Inseln Cypern und Rhodos. Prakt. Akad. Athènes, 4 : 301314.

ROTH, P.H., 1986. Mesozoic palaeoceanography of the North Atlantic and Tethys Oceans. In: C.P. Summerhayes and N.J. Shackleton (Editors), North Atlantic Paleoceanography. Geol. Soc. Spec. Publ. London, 21: 299-320.

ROTH, P.H., 1989. Ocean circulation and calcareous nannoplankton evolution during the Jurassic and Cretaceous. Palaeogeogr., Palaeoclimatol., Palaeoecol., 74: 111-126.

SENEL M. (1997). 1 :250 000 scale Geological Maps of Turkey, Marmaris and Fethiye Sheets. Gen. Dir. Min. Res. Expl. Ankara, Turkey.

THIÉBAULT F., DE WEVER P., FLEURY J.J. \& BASSOULET J.P. (1981). Précisions sur la série stratigraphique de la nappe du Pinde-Olonos de la presqu'île de Koroni (Péloponnèse méridional - Grèce) : 1'âge des Radiolarites - (Dogger - Crétacé supérieur). Ann. Soc. Géol. Nord , : 91-105. 